\title{
Giant Cell Arteritis: Clinical Guide for the Eyecare Professional
}

\author{
William D. Kress, OD, FAAO \\ Cincinnati Veterans Affairs \\ Medical Center
}

John M Neal, OD

Central Arkansas Veterans

Healthcare System

\section{ABSTRACT}

Purpose: The purpose of this article is to review giant cell arteritis, with a focus on ophthalmic manifestations, and provide a quick reference for clinical identification, diagnosis and appropriate management.

Summary: Giant cell arteritis is one of a few true medical emergencies that may present initially to the eyecare professional. An understanding the disease course and management will help the eyecare professional detect and manage this condition early in the disease process, potentially preventing blindness and life-threatening systemic manifestations.

\section{KEYWORDS}

Giant cell arteritis, ischemic optic neuropathy, polymyalgia rheumatica, temporal artery, glucocorticoid

\section{INTRODUCTION}

Giant cell arteritis (GCA), also known as temporal arteritis, is classified as a systemic vasculitis affecting medium and larger vessels. ${ }^{1,2}$ GCA is the most common of the systemic vasculitides that primarily affect people over 50 years of age. The clinical presentation of GCA, when it affects blood flow to the eye, is typically a sudden, unilateral, painless vision loss with or without other ocular findings. GCA affects women three times more than men, with an estimated incidence of 27 cases per 100,000 in those 50 years or older and a peak incidence of 70-80 years of age. ${ }^{3}$ Individuals of northern European, particularly Scandinavian, descent carry a higher risk than other ethnic groups. ${ }^{4}$ Suspected GCA is a medical emergency and must be managed as such until proven otherwise. In addition to significant vision loss, GCA can present as other ocular and/or systemic manifestations, such as headache, jaw claudication, cranial nerve palsies, peripheral neuropathies, scalp necrosis, altered mental status, congestive heart failure, myocardial infarction, aortitis, aortic aneurysm rupture, and thromboembolic events. ${ }^{5-14}$ The goal of this article is to provide the eyecare professional an update on the clinical presentation, diagnosis, and treatment options for GCA. 


\section{ETIOLOGY AND PATHOPHYSIOLOGY}

The exact etiology and pathogenesis of GCA remain unknown. However, several studies have demonstrated that the etiology may be multifactorial in nature, and involve both genetic and environmental factors. ${ }^{15-17}$ Temporal artery histopathology demonstrates segmental and focal panarteritis with non-necrotizing inflammation. In addition, CD4+ T lymphocytes, macrophages, and giant cells are found infiltrating the arterial walls, suggesting an immune response to a triggering antigen. ${ }^{18}$ Herpes zoster virus has been a proposed inciting antigen, however the literature remains inconclusive. ${ }^{19}$ Although a specific mechanism remains elusive, aging is accompanied by physiological changes leading to a reduction in the immune response, increased inflammation and oxidation, and an increased production of auto-antibodies, which creates an environment for an autoimmune response to antigens. ${ }^{20,21}$ The resultant inflammatory process leads to vascular compromise and tissue ischemia.

\section{CLINICAL PRESENTATION}

Approximately one in five patients diagnosed with GCA will present with only ocular signs or symptoms, without other systemic symptoms. ${ }^{1}$ It is estimated that one in three patients with GCA will present with either transient (amaurosis fugax) or permanent visual symptoms. ${ }^{22}$ Amaurosis fugax has been reported to affect 10-30\% of patients with GCA and carries a poorer visual prognosis. Transient visual symptoms may present uni- or bilaterally.,23

Permanent vision loss, to varying degrees, occurs in 5- 20\% of patients with confirmed GCA.4,24 The most common ocular manifestation is acute, painless, unilateral vision loss secondary to ischemic optic neuropathy. Arteritic ischemic optic neuropathy (A-AION) affects approximately $80 \%-85 \%$ of individuals with ocular GCA and the presenting acuity may range from 20/200 to no light perception (Figure 1).,24

Figure 1: Optic disc edema secondary to arteritic ischemic optic neuropathy

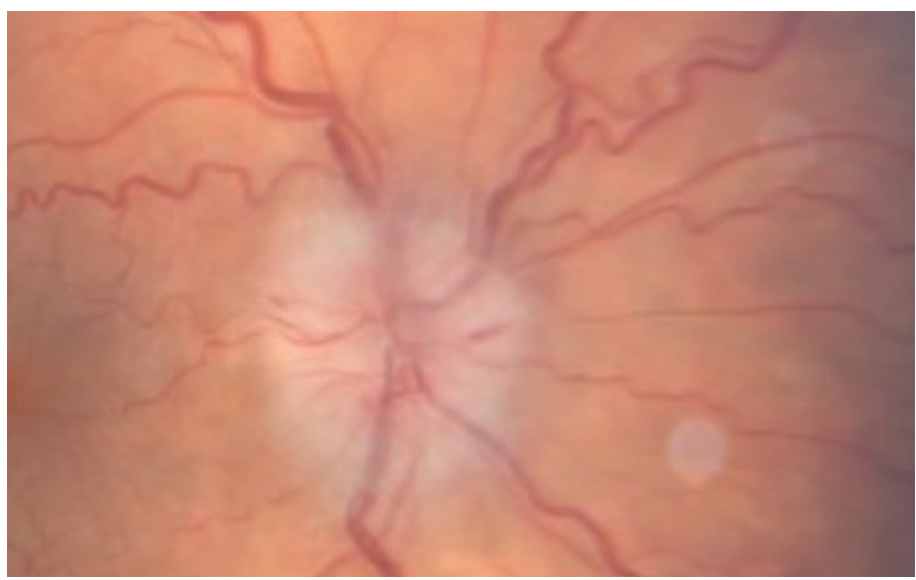

Ischemia to the posterior ciliary arteries and the short branches supplying the optic nerve head leads to a clinical appearance of an edematous, chalky-white colored nerve with or without surrounding intra-retinal hemorrhages. Optic atrophy develops within 6-8 weeks of the inciting event and typically appears as sectoral pallor without other retinal exam findings. A relative afferent pupillary defect will be present in unilateral cases without previous significant retinal or neurological events to the fellow eye. The automated visual field will show signs of either a complete or incomplete altitudinal defect that may or may not be absolute in nature (Figure 2). Although inferior or superior defects (relative or absolute) are the more commonly reported visual field defects associated with ischemic optic neuropathy, the pattern defects can take on an array of appearances based on the type of field (kinetic vs. static) as well as the testing size (i.e., I-le to I-4e, V-4e). ${ }^{25}$

Although disc edema may be more diffuse in A-AION, presentation can also be sectoral in nature. Arteritic posterior ischemic optic neuropathy (A-PION) is far less common than A-AION and presents similarly to A-AION without the typical fundoscopic findings. As such, A-PION is a diagnosis of exclusion. 
Figure 2: Absolute inferior altitudinal field cut with some central sparing secondary to ischemic optic neuropathy

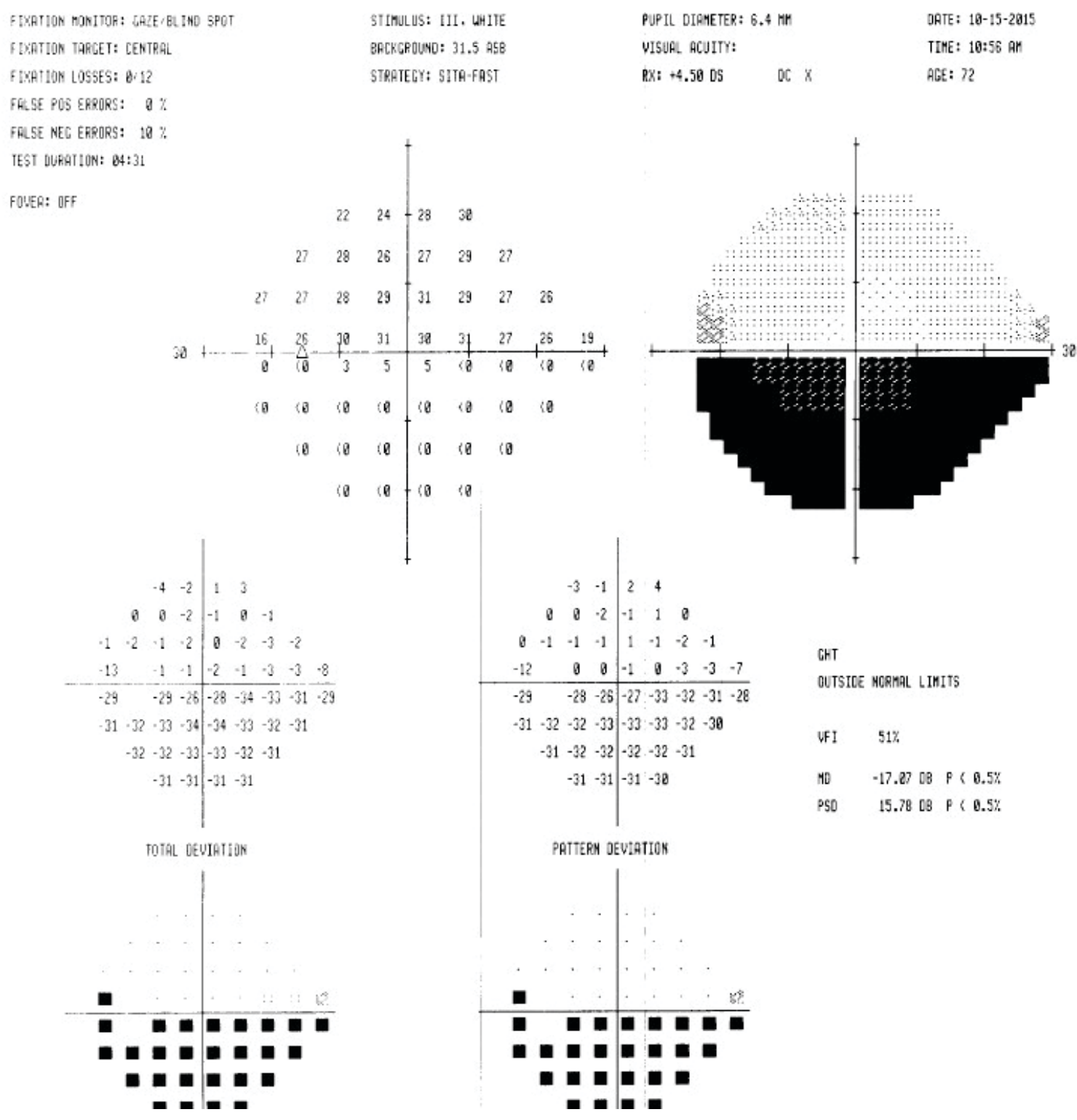

Other presentations of GCA-associated ocular findings include retinal ischemia (retinal artery occlusion, cilio-retinal artery occlusion, cotton wool spots), choroidal ischemia (small retinal hemorrhages and/or retinal pigmentary changes), anterior segment ischemia (hypotony, corneal edema, uveitis, rubeosis irides), ophthalmoplegia (cranial nerve palsy/palsies, orbital pseudotumor), scleritis, and ocular ischemic syndrome. ${ }^{26}$

Although GCA is typically characterized as a "head and neck" disease, systemic manifestations should be explored as part of the case history of a suspected GCA-related ocular complication presenting to the eyecare professional. Headache is the first symptom in $32-40 \%$ of GCA cases. ${ }^{27-29}$ Characteristic presentation is a new acute headache or a change in the pattern of previous headaches. The headache may often be localized, and occurs in the temporal region $25-50 \%$ of the time. ${ }^{30}$ The headache may be accompanied by jaw claudication (mandibular pain from repeti- 
tive chewing motion), pain in the tongue, or chest pain and odynophagia (pain on swallowing foods or fluids) due to aortitis. Giant cell arteritis can present with symptoms of fever, weight loss (40\% of cases) $)^{31}$ and general malaise.

Other systemic manifestations associated with GCA are listed in Table 1.

Table 1: Other systemic manifestations of $G C A^{32-45}$

\begin{tabular}{|l|l|}
\hline System & Signs/Symptoms \\
\hline central nervous & $\begin{array}{l}\text { transient ischemic attack } \\
\text { stroke } \\
\text { dementia } \\
\text { cranial neuropathy (other than ocular) }\end{array}$ \\
\hline peripheral nervous & $\begin{array}{l}\text { mono- and polyneuropathies } \\
\text { median nerve } \\
\text { C5-C6 roots }\end{array}$ \\
\hline cardiovascular & $\begin{array}{l}\text { aortitis, aortic dissection, aortic aneurysm, aortic stenosis } \\
\text { thoracic or abdominal aortic dissection or aneurysm } \\
\text { stenosis of cervical, brachial, subclavian, axillary or lower extremity artery }\end{array}$ \\
\hline respiratory & cough \\
\hline gastrointestinal and renal & $\begin{array}{l}\text { elevated liver enzymes } \\
\text { small-bowel infarction } \\
\text { renal and bladder disease (rare) }\end{array}$ \\
\hline reproductive & vascular involvement of breast and female genital tract \\
\hline integumentary & scalp necrosis, otherwise rare \\
\hline
\end{tabular}

In terms of systemic manifestations of GCA, the discussion must include polymyalgia rheumatica (PMR), due to the apparent association of the two disease processes. Approximately 40-60\% of patients diagnosed with GCA have PMR, and approximately $16-21 \%$ of PMR patients have GCA. ${ }^{13,46-48}$ A PMR diagnosis is based on clinical features that include acute, bilateral shoulder pain and stiffness and/or pelvic girdle aching for more than two weeks. In addition, constitutional symptoms of fever, fatigue, weight loss, depression, and night sweats are frequent. ${ }^{46}$

DIAGNOSTIC WORK-UP

The 1990 American Academy of Rheumatology criteria for the classification of GCA are currently used as the standard for diagnosis of the condition (Table 2). The presence of three or more of the five criteria carries a sensitivity of $93.5 \%$ and a specificity of $91.2 \%{ }^{49}$

Table 2: Criteria for diagnosis of $G C A^{49}$

\begin{tabular}{|l|l|}
\hline System & Signs/Symptoms \\
\hline 2. Age at disease onset $\geq 50$ years & Development of symptoms or findings beginning at age 50 or older \\
\hline 3. Temporal artery abnormality & New onset or new type of localized pain in the head \\
\hline 4. Elevated erythrocyte sedimentation rate & $\begin{array}{l}\text { Temporal artery tenderness to palpation or decreased pulsation, unrelated to } \\
\text { arteriosclerosis of cervical arteries }\end{array}$ \\
\hline 5. Abnormal artery biopsy & $\begin{array}{l}\text { Biopsy specimen with artery showing vasculitis characterized by } \\
\text { a predominance of mononuclear cell infiltration or granulomatous } \\
\text { inflammation, usually with multinucleated giant cells }\end{array}$ \\
\hline
\end{tabular}

The combination of ESR with C-reactive protein (CRP) increases the specificity of a GCA diagnosis than is available with either test alone, whereas a few studies have shown that CRP $(>2.45 \mathrm{mg} / \mathrm{dL})$ alone is highly sensitive to this condition. ${ }^{50,51}$ Of note, approximately $4-14 \%$ of temporal artery biopsy-proven cases of GCA may have a normal ESR 
and CRP. ${ }^{52,53}$ Several studies have proposed that thrombocytosis (elevated platelet count) may be a useful predictor in conjunction with ESR and CRP in the diagnosis of GCA..$^{51,54,55}$

Laboratory testing and patient symptoms help predict the likelihood of GCA. However, temporal artery biopsy (TAB) remains the standard test for clinically-proven GCA. TAB carries a diagnostic sensitivity of $70-90 \% .^{22}$ Among patients with negative TAB studies, further GCA investigation may be indicated in cases with high suspicion based on lab work-up and clinical signs and symptoms. For those with large-vessel disease, such as GCA affecting the aorta, immediate branches of the aorta, larger upper and lower extremity vessels, or individuals carrying a high suspicion of GCA despite a negative TAB, recent literature suggests that imaging techniques may be useful for confirming a diagnosis..$^{56-59}$ Additional techniques for the diagnosis of GCA include Doppler ultrasonography, computed tomography (CT) and computed tomography angiography (CTA), magnetic resonance imaging (MRI) and magnetic resonance angiography (MRA), and positron emission tomography (PET) using 18F-fluorodeoxyglucose (FDG).

\section{MANAGEMENT}

Given the potential negative visual and systemic outcomes of GCA, medical therapy is generally initiated upon a diagnosis of suspicion. For the eyecare professional managing a patient with signs or symptoms of GCA, the most likely course of action will be immediate referral to a tertiary eyecare specialist or local emergency room with instructions for suspicion of GCA. If available, a cursory blood work-up is appropriate and should focus on complete blood count, ESR, and CRP.

Glucocorticoid therapy is the primary treatment in suspected or biopsy-proven GCA. However, the optimal dosage and regimen for initial therapy and long-term management remains a matter of debate and focuses more on individualized management. Current practice is to dose anywhere from 20 to $60 \mathrm{mg} /$ day of prednisolone with the aim of suppressing GCA-related symptoms. While the tapering of glucocorticoids is desired given systemic side effects, therapy may go on for months to years based on the individual response to treatment. $56,60-64$

For visually-symptomatic GCA, existing recommendations are for intravenous glucocorticoid therapy (methylprednisolone $\mathrm{lg} / \mathrm{day}$ for 3 consecutive days) with oral prednisolone $(15 \mathrm{mg} / \mathrm{kg} / \mathrm{day})$ and continued oral glucocorticoid tapering based on the individual patient signs and symptoms. ${ }^{65}$ For patients who already have visual impairment, earlier treatment (within 24hrs) yields the best chance of visual recovery. ${ }^{61,62,66}$ Visual symptoms without strong evidence of GCA may initially be treated with oral therapy alone. Like large-vessel non-ocular disease treatment, there are no clear guidelines on effective dosage or duration, and management is individualized to the patient's signs and symptoms.

As with any glucocorticoid treatment, especially long-term care, systemic side effects and the risk of complications associated with steroid therapy raise the question of other management options for GCA. FDA-approved sub-cutaneous administration of tocilizumab (TCZ) has been shown to offer immediate and long-term efficacy in GCA treatment. Several studies have shown that it is effective for inducing remission of initial GCA-related signs/ symptoms. ${ }^{67-69}$ The GiACTA trial demonstrated that tocilizumab is effective for the management of new or relapsing GCA in conjunction with a glucocorticoid taper of 52 weeks, where the overall dosage of glucocorticoids is reduced as needed to prevent relapse. ${ }^{70}$ The role of TCZ in the management of occult visual changes associated with GCA is unclear at this time. Adjunctive therapy may include aspirin, statins, and/or angiotensin II receptor blockers due to their anti-inflammatory properties, anti-coagulative properties, and potential for reduced relapse, and has been found to be beneficial in observational studies and animal models. ${ }^{7-75}$ Large-scale randomized clinical trials are needed to confirm their roles in the management of GCA.

\section{PROGNOSIS}

The prognosis of GCA-related vision loss is typically guarded for the initial event. Although significant recovery from ischemic optic neuropathy events has been documented, ${ }^{75}$ management is focused on prevention of fellow-eye involvement, with approximately $50 \%$ of individuals affected within days to weeks of the initial event. ${ }^{13,77}$ Relapse of GCA is a concern for the managing healthcare professional. It is estimated that $43-80 \%$ of patients experience GCA-related relapse within 1 to 2 years after the initial event. ${ }^{78-82}$ Although ischemic events, such as ischemic optic neuropathy, are not characteristic in relapse events, headache, PMR symptoms, and constitutional symptoms (myalgia, malaise, fever, nausea) may reflect recurrence. ${ }^{4,25,82}$

\section{CONCLUSION}

Giant cell arteritis may initially present as acute vision loss. Signs or symptoms associated with GCA-related vision loss must be handled as a medical emergency. The eyecare professional must take immediate action and assess the true risk of GCA based on the findings. If the diagnosis is uncertain given the case history, exam findings, or cursory blood work-up, the ocular manifestations should be treated as GCA until proven otherwise. $\bullet$ 


\section{REFERENCES}

1. Hayre SS, Podhajsky PA, Zimerman B. Occult giant cell arteritis: ocular manifestations. Am J Ophthalmol 1998;125(4):521-6.

2. Ninan J, Lester S, Hill C. Giant cell arteritis. Best Pract Res Clin Rheumatol 2016;30(1):169-88.

3. Aiello PD, Trautmann JC, McPhee TJ, Kunselman AR, Hunder GG. Visual prognosis in giant cell arteritis. Ophthalmology 1993;100(4):550-5.

4. Carmona FD, Vaglio A, Mackie SL, et al. A genome-wide association study identifies risk of alleles in plasminogen and P4HA2 associated with giant cell arteritis. Am J Hum Genet 2017;100(10):64-74. doi. org/10.1016/j.ajhg.2016.11.013.

5. Save-Soderbergh J, Malmvall BE, Andersson R, Bengtsson BA. Giant cell arteritis as a cause of death. Report of nine cases. JAMA 1986;255:493-6.

6. Hupp SL, Nelson GA, Zimmerman LE. Generalized giant-cell arteritis with coronary involvement and myocardial infarction. Arch Ophthalmol 1990;108:1385-7.

7. Morris CR, Scheib JS. Fatal myocardial infarction resulting from coronary arteritis in a patient with polymyalgia rheumatic and biopsy-proven temporal arteritis. A case report and review of literature. Arch Intern Med 1994;154:1158-60.

8. Evans JM, O, Fallon WM, Hunder GG. Increased incidence of aortic aneurysm and dissection in giant cell(temporal)arteritis. A population-based study. Ann Intern Med 1995;122:502-7.

9. Caselli RJ, Daube JR, Hunder GG, Whisnant JP. Peripheral neuropathic syndromes in giant cell(temporal)arteritis. Neurology 1988;38:685-9.

10. Unwin B, Williams CM, Gilliland W. Polymyalgia rheumatic and giant cell arteritis. Am Fam Physician 2006;74:1547-54

11. Pascuzzi RM, Roos KL, Davis TE, Jr. Mental status abnormalities in temporal arteritis: a treatable cause of dementia in the elderly. Arthritis Rheum 1989;32:1308-11.

12. Weyand CM, Goronzy JJ. Giant cell arteritis and polymyalgia rheumatic. Ann Int Med 2003;139:505-15.

13. Hellman DB, Hunder GG. Giant cell arteritis and polymyalgia rheumatica. In: Harris ED, Budd RC, Genovese MC, Firestein GS, Sargent JS, Sledge CB (eds). Kelley's Textbook of Rheumatology, 7th ed. Philadelphia, PA: Elsevier Saunders;2005:1343-56.

14. Ross M, Bursztyn L, Superstein R, Gans M. Multiple cranial nerve palsies in giant cell arteritis. J Neuroophthalmol 2017;37(4):398-400.

15. Chen M, Gelman R, Al-Zubidi N, et al. Conjugal giant cell arteritis. J Neuro-Ophthalmol 2013;33:158-61.

16. Watts RA, Scott DG. Epidemiology of vasculitides. Semin Resp Crit Care Med 2004;25:455-64

17. Smith CA, Fidler WJ, Pinals RS. Giant cell arteritis. Report of a ten-year study in Shelby County, Tennessee. Arthritis Rheum 1983;26:1214-9.

18. Buckingham EM, Foley MA, Grose C, et al. Identification of herpes zoster-associated temporal arteritis among cases of giant cell arteritis. Am J Ophthalmol 2018;187:51-60. doi.ord/10/1016/j. ajo.2017.12.017.

19. Lee HY, Oh BH. Aging and artery stiffness. Circ J 2010;74(11):2257-62.

20. Wang M, Monticone RE, lakatta EG. Arterial aging: a journey into subclinical arterial disease. Curr Opin Nephrol Hypertens 2010;19(2):201-7.

21. Borchers AT, Gershwin ME. Giant cell arteritis: a review of classification, pathophysiology, geoepidemiology and treatment. Autoimmun Rev 2012;11(6-7):A544-54.

22. Salvarini C, Cantini F, Boiardi L, Hunder GG. Polymyalgia rheumatica and giant cell arteritis. N Engl J Med 2002;347(4):261-7.

23. Chen JJ, Leavitt JA, Fang C, Crowson CS, Matteson EL, Warrington KJ. Evaluating the incidence of arteritis ischemic optic neuropathy and other causes from giant cell arteritis. Ophthalmology 2016;123(9):1999-2003. doi:10.1016/j.ophtha.2016.05.008.

24. De Smit E, O'Sullivan E, Mackey DA, Hewitt AW. Giant cell arteritis: ophthalmic manifestations of a systemic disease. Graefes Arch Clin Exp Ophthalmol 2016;254:2291-306.

25. Hayreh SS, Zimmerman B. Visual field abnormalities in non-arteritic ischemic optic neuropathy. Arch Ophthalmol 2005;123:1554-62.

26. Smeeth L, Cook C, Hall AJ. Incidence of diagnosed polymyalgia rheumatica and temporal arteritis in the United Kingdom, 19902001. Ann Rheum Dis 2006;65(8):1093- 8.
27. Gonzalez-Gay MA, Amoli MM, Garcia-Porrua C, Ollier WE. Genetic markers of disease susceptibility and severity in giant cell arteritis and polymyalgia rheumatica. Semin Arthitis Rheum 2003;33(1):38-48.

28. Caselli RJ, Hunder GG, Whisnant JP. Neurologic disease in biopsyproven giant cell(temporal)arteritis. Neurology 1988;38(3):352-9. doi.org/10.1212/WNL.38.3.352.

29. Solomon S, Cappa KG. The headache of temporal arteritis. J Am Geriatr Soc 1987;35(2):163-5. doi.org/10.1111/j.1532-5415.1987. tb01348.x.

30. Healey LA, Wilske KR. Presentation of occult giant cell arteritis. Arthritis Rheum 1980;23(6):641-3. doi.org/10.1002/art.1780230605.

31. Smith JH, Swanson JW. Giant cell arteritis. Headache 2014;54(8):1273-89.

32. Weyand CM, Goronzy JJ. Medium- and large-vessel vasculitis. N Engl J Med 2003;349(2):160-9. doi:10.1056/NEJMra022694.

33. Tang V, Fantaneanu T, Chakraborty S, Patel V, Dowlatshahi D. Intracranial non-occlusive thrombus and multiple strokes in giant cell arteritis. Can J Neurol Sci 2012;39(1):116-7.

34. Schon F. Involvement of smell and taste in giant cell arteritis. J Neurol Neurosurg Psychiatry 1988;51(12):1594.

35. Roomet A, Allen JS. Temporal arteritis heralded by facial nerve palsy. JAMA 1974;228(7):870-1. doi.org/10.1001/ jama.1974.03230320040027.

36. Solans-Laque R, Bosch-Gil JA, Molina-Catenario CA, Ortega-Aznar A, Alvarez-Sabin J, Vilardell-Tarres M. Stroke and multi-infarct dementia as presenting symptoms of giant cell arteritis: report of 7 cases and review of literature. Medicine 2008;87(6):335-44.

37. Nuenninghoff DM, Hunder GG, Christianson TJ, McClelland RL, Matteson EL. Mortality of large-artery complication(aortic aneurysm, aortic dissection, and/or large-artery stenosis)in patients with giant cell arteritis: a population-based study over 50 years. Arthritis Rheum 2003;48(12):3532-7.

38. Kermani TA, Warrington KJ, Crowson CS, et al. Large-vessel involvement in giant cell arteritis: a population-based cohort study of the incidence-trends and prognosis. Ann Rheum Dis 2013;72(12):1989-94.

39. Olopade CO, Sekosan M, Schraufnagel DE. Giant cell arteritis manifesting as chronic cough and fever of unknown origin. Mayo Clin Proc 1997;72(11):1048-50.

40. Killer HE, Holtz DJ, Kaiser HJ, Laeng RH. Diplopia, ptosis and hepatitis as presenting sign and symptoms of giant cell arteritis. $\mathrm{Br}$ J Ophthalmol 2000;84(11):1319-20.

41. Burke AP, Sobin LH, Virmani R. Localized vasculitis of the gastrointestinal tract. Am J Surg Pathol 1995;19(3):338-49.

42. Kadotani Y, Enoki Y, Itoi N, Kojima F, Kato G, Lee CJ. Giant cell arteritis of the breast: a case report with review of literatures. Breast Cancer 2010;17(3):225-32. doil0.1007/s12282-009-0120-1.

43. Pradhan D, Amin RM, Jones MW, Surti U, Parwani AV. Giant cell arteritis of the female genital tract with occult temporal arteritis and marginal zone lymphoma harboring novel 20q deletion: a case report and literature review. Int J Surg Pathol 2016;24(1):78-84.

44. Gibson LE. Granulomatous vasculitides and the skin. Dermatol Clin 1990;8(2):335-45.

45. Kermani TA, Warrington KJ. Polymyalgia rheumatica. Lancet 2013;381(9860):63-72

46. Salvarani C, Gabriel SE, O'Fallon WM, Hunder GG. The incidence of giant cell arteritis in Olmsted County, Minnesota: apparent fluctuations in a cyclic pattern. Ann Intern Med 1995;123(3):192-4.

47. Franzen P, Sutinen S, von Knorring J. Giant cell arteritis and polymyalgia rheumatica in a region of Finland: an epidemiologic. Clinical and pathologic study, 1984-1988. J Rheumatol 1992;19(2):273-6.

48. Hunder GG, Bloch DA, Michel BA, et al. The American Academy of Rheumatology 1990 criteria for the classification of giant cell arteritis. Arthritis Rheum 1990;33(8):1122-8.

49. Kermani TA, Schmidt J, Crowson CS, Ytterberg SR, Hunder GG, Matteson EL, et al. Utility of erythrocyte sedimentation rate and C-reactive protein for the diagnosis of giant cell arteritis. Semin Arthritis Rheum 2012;41(6):866-71. doi:10.1016/j.semarthrit.2011.10.005.

50. Walvick MD, Walvick MP. Giant cell arteritis: laboratory predictors of a positive temporal artery biopsy. Ophthalmology 2011;118(6):1201-4 
51. Salvarani C, Hunder GG. Giant cell arteritis with low erythrocyte sedimentation rate: frequency of occurrence in a population-based study. Arthritis Rheum 2001:45:140-5.

52. Parikh M, Miller NR, Lee AG, et al. Prevalence of a normal Creactive protein with an elevated erythrocyte sedimentation rate in biopsy-proven giant cell arteritis. Ophthalmology 2006;113:1842-5.

53. El-Dairi MA, Chang L, Proia AD, Cummings TJ, Stinnett SS, Bhatti MT. Diagnostic algorithm for patients with suspected giant cel arteritis. J Neuroophthalmol 2015;35(3):246-53.

54. Oh LJ, Wong E, Andrici J, McClucskey P, Smight JEH, Gill AJ. The full blood count in giant cell arteritis. Intern Med J 2018 Apr;48(4):408-13.

55. Nina JW, Lester S, Hill CL. Giant cell arteritis: beyond temporal artery biopsy and steroids. Intern Med J 2017;47:1228-40.

56. Descamps L, Olagne L, Merlin C, Cachin F, Soubrier M, Mathieu $\mathrm{S}$. Utility of PET/CT in the diagnosis of inflammatory rheumatic disease: a systematic review and meta-analysis. Ann Rheum Dis 2018 Nov;77(11):e81.

57. Buttgereit F, Dejaco C, Matteson EL, Dasgupta B. Polymyalgia rheumatica and giant cell arteritis. A systematic review. JAMA 2016;315(22):2442-58.

58. Jacquier P, Wuarin R, Chizzolini C, Thumann G, Steffen H, Chronopoulos A. Case report: Masquerading large-vessel giant cell arteritis. Optom Vis Sci 2017;94(12):1159-64.

59. Labarca C, Koster MJ, Crowson CS, et al. Predictors of relapse and treatment outcomes in biopsy-proven giant cell arteritis: a retrospective cohort study. Rheumatology 2016;55:347-56.

60. Bienvenu B, Ly KH, Lambert M, et al. Management of giant cell arteritis: recommendations of the French study group for large vesse vasculitis(GEFA). Rev Med Intern 2016;37:154-65.

61. Dasgupta B, Borg FA, Hassan N, et al. BSR and BHPR guidelines for the management of giant cell arteritis. Rheumatology 2010;49:1594-7.

62. Dejaco S, Singh YP, Perel P, et al. European League Against Rheumatism. 2015 recommendations for the management of polymyalgia rheumatica: a European League Against Rheumatism/American College of Rheumatology collaborative initiative. Arthritis Rheumatol 2015;67(10):2569-80.

63. Mukhtyar C, Guillevin L, Cid MC, et al. European Vasculitis Study Group. EULAR recommendations for the management of large vessel vasculitis. Ann Rheum Dis 2009;68(3):318-23.

64. Frasier JA, Weyand CM, Newman NJ, Biousse V. The treatment of giant cell arteritis. Rev Neurol Dis 2008;5(3):140-52.

65. Mazlumzadeh M, Hunder GG, Easely KA, et al. Treatment of giant cell arteritis using induction therapy with high dose glucocorticoids: a double-blind, placebo-controlled, randomized prospective clinical trial. Arthritis Rheum 2006;54:3310-8.

66. Seitz M, Reichenbach S, Bonel HM, Adler S, Wermelinger F, Villiger PM. Rapid induction of remission of large vessel vasculitis by IL-6 blockade. A case series. Swiss Med Wkly 2011;141:w13156

67. Regent A, Redecker S, Deroux A, et al. Tocilizumab in giant cel arteritis: a multicenter retrospective study of 34 patients. J Rheumatol 2016;43(8):1547-52.
68. Maini RN, Taylor PC, Szechinski J, et al Double-blind randomization controlled clinical trial of the interleukin-6 receptor antagonist, tocilizumab, in European patients with rheumatoid arthritis who had an incomplete response to methotrexate. Arthritis Rheum 2006;54(9):2817-29.

69. Stone JH, Tuckwell K, Dimonaco S, et al. Trial of tocilizumab for giant cell arteritis. N Eng J Med 2017;377(4):317-28

70. Schmidt WA. Seifert A, Gromnica-Ihle E, Krause A, Natusch A. Ultrasound of proximal upper extremity arteries to increase the diagnostic yield in large-vessel giant cell arteritis. Rheumatology 2008;47:96-101.

71. Souza AW, Okamoto KY, Abrantes F, Schau B, Bacchiega AB, Shinjo SK. Giant cell arteritis: a multicenter observational study in Brazil. Clinics 2013;68:317-22.

72. Scmhidt J, Kermani TA, Muratore F, Crowson CS, Matteson EL, Warrington KJ. Statin use in giant cell arteritis: a retrospective study. J Rheumatol 2013;40:910-5.

73. Pugnet G, Sailer L, Bourrel R, Montastruc JL, Lapeyre-Mestre M. Is statin exposure associated with occurrence or better outcome in giant cell arteritis? Results from a French population-based study. J Rheumatol 2015;42:316-22.

74. Alba MA, Garcia-Martinez A, Prieto-Gonzalez S, et al. Treatment with angiotensin II receptor blockers is associated with prolonged relapse-free survival, lower relapse rate, and corticosteroid-sparing effect in patients with giant cell arteritis. Semin Arthritis Rheum 2014;43:772-7.

75. Thurtell MJ, Kardon RH. Recovery of vision from no light perception in giant cell arteritis. Arch Ophthalmol 2012;130(8):1080-2.

76. Birkhead NC, Wagener HP, Schick RM. Treatment of temporal arteritis with adrenal corticosteroids: results in 55 cases in which lesion was proven at biopsy. JAMA 1958;163:821-7.

77. Bongartz T, Matteson EL. Large-vessel involvement in giant cell arteritis. Curr Opin Rheumatol 2006;18:10-7.

78. Cid MC, Garcia-Martinez A, Lozano E, et al. Five clinical conundrums in the management of giant cell arteritis. Rheum Dis Clin North Am 2007;33:819-34, vii.

79. Hoffman, GS, Cid MC, Hellmann DB, et al. A multicenter, randomized, double-blind, placebo-controlled trial of adjuvant methotrexate treatment for giant cell arteritis. Arthritis Rheum 2002;46:1309-

80. Jover JA, Hernandez-Garcia C, Morado IC, et al. Combined treatment of giant cell arteritis with methotrexate and prednisone. A randomized, double-blind, placebo-controlled trial. Ann Intern Med 2001;134:106-14.

81. Alba, MA, Garcia-Martinez A, Prieto-Gonzalez S, et al. Relapse in patients with giant cell arteritis: Prevalence, characteristics, and associated clinical findings in a longitudinally followed cohort of 106 patients. Medicine 2014;93(5):194-201.

82. Martinez-Lado L, Calvina-Diaz C, Pineiro A, et al. Relapses and recurrences in giant cell arteritis: a population-based study of patients with biopsy-proven disease from northwestern Spain. Medicine 2011;90:186-93. 